Hipotenusa : Journal of Mathematical Society

Volume 3 Issue 1 Year 2021

ISSN: $2716-3156$

Website: https://hipotenusa.iainsalatiga.ac.id/index.php/hipotenusa/index

\title{
The Feasibility Analysis of Mathematics Textbook Material based on Bell's Criteria
}

\author{
Mahendra Wisnu Wardana ${ }^{1^{*}}$, Leetahannee $\operatorname{Kadah}^{2}$ \\ ${ }^{1}$ SMP API Al Huda Magelang, Indonesia \\ ${ }^{2}$ Sekolah Saengtham, Thailand \\ *Corresponding Author, e-mail: mahendrawisnu51@ gmail.com \\ DOI: 10.18326/hipotenusa.v3i1.1-24
}

$\begin{array}{ll}\text { Article submitted } & \text { : February 5, 2021 } \\ \text { Article reviewed } & \text { : April 22, 2021 } \\ \text { Article published } & \text { : June 1, 2021 }\end{array}$

\begin{abstract}
The purpose of this study is to determine the feasibility of Mathematics textbook material for Grade VII 1st semester on 2017 Revised Edition based on Bell's criteria. So that if there is an error, it can be fixed. Then, this type of research is descriptive research. In the descriptive analysis, there is no need to find or explain its relationships and test hypotheses. The approach used is qualitative. Moreover, this study uses a qualitative approach because the data collected are described in sentences. This study will be obtained from two sources, namely the main source of the Mathematics Textbook Grade VII of 2013 curriculum and peer-discussion support sources. The method used in this research is the documentation method. The documentation data used in this research is the textbook itself. However, the data obtained by using the Analysis Instrument Result shows that the suitability of the mathematics textbook material of Grade VII with the material based on Bell's criteria for the numbers and algebra chapters includes a good category. Meanwhile, the sets and equations and linear inequalities of one variable chapter belong to be an excellent category. The average suitability of the mathematics material from each chapter in the textbook toward Bell's criteria is $83.75 \%$ and is supported by the validity data results through forms and peer discussions. As a result, the feasibility of the mathematics textbook material for grade VII of the 2017 revised edition based on Bell's criteria is very good.

Keywords: analysis of mathematical textbook; grade vii, Bell criteria
\end{abstract}

\section{INTRODUCTION}

Learning experiences are the main activities in the educational process. National education in Indonesia is defined as a conscious and planned effort to create a learning atmosphere and learning process so that students actively develop their potential to achieve certain goals, which are characterized by the involvement of a number of interrelated components. Moreover, the studying and learning process elements are 
called learning tools that consist of a lesson plan, learning tools/instruments that include methods, media and learning resources, and evaluation tools, both tests and non-tests (Hanafy, 2014).

Learning resources are needed to support the teaching and learning process in schools, from elementary to higher education. Then, one of the most widely used learning resources in schools is textbooks. Textbooks help teachers in delivering material, while for students, textbooks support them in mastering the material and could be used for independent learning (auto-pilot learner). (Rahmawati G., 2015) The use of textbooks is inseparable from the selection process seen from the objectives, learning orientation, and student development to make it easier for students to master teaching material in the textbooks. Therefore, textbooks are books whose presence is needed by students in the class' supporting the learning process and as material for independent learning outside the classroom.

Before being used by the academic units, the textbooks have passed the textbook's feasibility test of the various components. In presenting materials, books must contain perfect elements because they will be used as sources of information for teachers and students. Pradita and Fitriani (2018: 282) state that the world of education in Indonesia has always paid close attention to the feasibility of textbooks in every discipline since a long time ago. There are various rules and criteria for determining the feasibility of composing and presenting a book. The government has made efforts to provide quality textbooks. As a result, the government there is the formation of the National Education Standards Agency (BSNP), one of the duties is to assess the feasibility of textbooks. In the Regulation of the Minister of National Education of the Republic of Indonesia (Permendiknas RI) No. 2 of 2008 concerning the book of Article 4, Paragraph 1 states that "Textbooks at the primary and secondary education levels are assessed for their feasibility first by the National Education Standards Agency (BSNP) before being used by educators and/or students as a learning resource." So, if each academic unit wants to use a textbook to help the process of teaching and learning activities, it is required to have a BSNP.

The National Education Standards Agency (BSNP) has its own criteria for textbooks used in the learning process. (Muljono, 2007) explains the criteria for a good textbook, namely first, at least it refers to students' achieved goal, in this case, is the 
competency standards ( $\mathrm{SK}$ and $\mathrm{KD}$ ), secondly contains information, messages, and knowledge which are written and able to be communicated to the readers (especially teachers and students) logically, easily accepted based on the readers' cognitive development level. Then third, it contains attractive and interactive presented concepts and interactive manner which can encourage critical, creative, innovative and deep thinking processes, as well as metacognition and self-evaluation, the fourth is based on its appearances, it would present an attractive cover and describes the characteristics of textbooks, 'read and use' eligibility and books' appearance quality.

When compared BSNP criteria with Bell's criteria, both have similarities with the material; SK and KD, material suitability, and material accuracy. Bell (Melissa, 2015) said that mathematics material in the textbooks must be correct and must be adjusted to the learning objectives and the type of students who will take part in the learning. The method of delivering the material is also an essential thing in book evaluation. The importance of evaluating mathematics textbooks is to determine the suitability of these books with the intellectual development's level and the students' ability level.

The government in Indonesia is currently implementing a 2013 curriculum education system. The textbooks used also follow curriculum changes, including grade VII semester 1 mathematics textbooks revised edition 2017. However, not all academic units in Indonesia use this textbook. Each education unit should have used the latest edition of the book because it supports the teaching and learning process in schools and is adjusted to the current curriculum.

Based on the description above, to prove the feasibility of the contents in the 2013 revised edition 2017 curriculum mathematics book for grade VII semester 1, an analysis of the book was carried out using Bell's criteria. The reason for taking the book was because the 2013 revised edition 2017 curriculum mathematics book for grade VII semester 1 was a book copyrighted by the Ministry of Education and Culture of the Republic of Indonesia in 2017, which was used as a learning resource. Since most schools in Indonesia use these books, it is necessary to guarantee their quality. This research was conducted to determine the feasibility of a Mathematics textbook based on Bell's Criteria. 
Hipotenusa Journal, 3 (1), June 2021

Mahendra Wisnu Wardana, Leetahannee Kadah

\section{METHOD}

This type of research used for this research is descriptive research. (Hardani, 2020) Descriptive analysis is directed to provide symptoms, facts, or events systematically and accurately regarding the characteristics of a particular population or area. There tends to be no need to find or explain mutual relationships and test hypotheses in descriptive research.

The approach used by researchers for this research is qualitative. According to (Sugiyono, 2018) qualitative can be used to examine the conditions of natural objects, where the researcher is a crucial instrument, data analysis is inductive/qualitative. This study uses a qualitative approach because the data collected will be presented in words arranged in a sentence.

This study analyzes the feasibility of the mathematics textbook material for grade VII of the 2017 revised edition based on Bell's criteria. The description in this study is carried out by providing an overview and an overall assessment of the textbook based on Bell's criteria relating to mathematical material.

The research is conducted by analyzing the feasibility of the mathematics textbook material for grade VII of the 2017 revised edition on 1st semester based on Bell's criteria. Due to the Covid-19 pandemic for data validity, peer is taken from peeronline discussions with junior high school teachers. The time of the research is carried out on June 22, 2020, until finished.

Therefore, The analyzed book is a 2013 curriculum mathematics textbook entitled SMP / MTs Mathematics Grade VII 1st Semester (Matematika SMP/MTs Kelas VII Semester 1), published by the Ministry of Education and Culture of the Republic of Indonesia at 2017 in the City of Jakarta with ISBN 978-602-282-984-3. Reviewed by Agung Lukito, Ali Mahmudi, Turmudi, M. Nanang Priatna, Yudi Satria, and Widowati. The data in this study is the suitability of the material in the 2013 Curriculum Mathematics Book of 2017 Revised Edition Grade VII Semester 1 based on Bell's first criteria, namely the criteria related to mathematics material.

This research, it will be obtained from two sources. The primary source is the 2013 Curriculum Mathematics Book, 2017 Revised Edition, Grade VII 1 st Semester, and supporting sources from peer discussion. Then, the method used in this research is the documentation method. According to (Hardani, 2020), the documentation method 
comes from the word document, which means written goods. Meanwhile (Rasimin, 2019) defines a process of collecting data that comes from non-human sources. So, the documentation method means how to collect data by recording the existing data. Documents can be in writings, pictures, or monumental works of a person. Documents included in the report include diaries, life histories, stories, biographies, regulations, policies. Though, documentation data used in this study is the 2013 Curriculum Mathematics textbook of 2017 Revision Edition Grade VII 1st Semester. Data obtained using the Book Conformity Analysis Sheet instrument based on Bell's criteria are in the form of a checklist. This check-list is filled by placing a checkmark $(\sqrt{ })$ in one of the "yes" or "no" columns based on the analysis result of the book's suitability to Bell's criteria.

Moreover, (Hardani, 2020) argues that data analysis is the process of systematically searching and compiling data obtained from interviews, field notes, and documentation by organizing data into categories, describing them into units, synthesizing, arranging them into patterns., choosing which ones are important and what will be studied, and making conclusions so that they are easily understood by oneself and others. The data analysis model in this study uses the data analysis model of Miles and Huberman. In (Hardani, 2020) the data analysis of Miles and Huberman's model is divided into three lines, (1) data reduction, (2) data presentation and (3) drawing conclusions. Data reduction in this study focuses on the suitability of the 2013 curriculum of the 2017 revised edition of mathematics textbook material for grade VII 1st semester based on Bell's Criteria.

Furthermore, the data presented will be presented in the narrative text from a brief description and results in analysis table of the suitability of the material in the textbook and then conclusions drawn from the results. The data analyzed in this study are book suitability data which come from research's documentation method. The book suitability data analysis technique can be described as follows.

In this study, the feasibility of the mathematics textbook material for grade VII 1 st semester of 2017 revised edition based on Bell's criteria published by the Ministry of Education and Culture in 2017 will be analyzed starting from the chapter I to chapter IV. The titles of the chapter are (1) Numbers (2) Sets (3) Algebraic Forms (4) One 
Hipotenusa Journal, 3 (1), June 2021

Mahendra Wisnu Wardana, Leetahannee Kadah

Variable Linear Equations and Inequalities. The eligibility data for this book will be processed using the formula:

$$
p=\frac{q}{q_{c}} \times 100 \%
$$

means:

$p=$ Book suitability percentage

$q=$ number of suitable questions

$q_{c}=$ number of questions

The results percentage of the textbook' suitability is then categorized into predicates which are in line with the percentage based on table 1. The percentage category of the material suitability is the result of modification from Arikunto (in Lutviana, 2017: 39-40) as follows.

Table 1. Percentage Category of Suitability Material

\begin{tabular}{ll}
\hline $\begin{array}{l}\text { Suitability } \\
\text { Percentage }\end{array}$ & Category \\
\hline $80 \%<p \leq 100 \%$ & Very Good \\
$60 \%<p \leq 80 \%$ & Good \\
$40 \%<p \leq 60 \%$ & Enough \\
$20 \%<p \leq 40 \%$ & Less \\
$p \leq 20 \%$ & Very Less \\
\hline
\end{tabular}

To check the validity of the data, an examination technique is needed. There are four criteria used, namely the degree of trust, transferability, dependability, and certainty. (1) The trust degree has the function to carry out an inquiry in such a way so that the confidence's level of the inventor can be achieved and shows the confidence's level of one finding by the researcher's prove (Moleong, 2017). (2) Transferability means that an invention can be used or applied to all contexts. To carry out this diversion, the researcher looks for and collects the empirical events of the similarity in context (Moleong, 2017). (3) Dependency is a substitute for the term reliability, which is indicated by conducting a replication of the study. Reliability happens when a study is repeated in the same condition and gets the same results (Moleong, 2017). (4) Certainty, the criterion of certainty, comes from the concept of objectivity according to nonqualitative terms, which is determined in terms of the agreement among subjects. The 
thing could be objective or not depend on the agreement of several people toward views, opinions, and findings. It could be accurate if it is agreed upon by few people or many (Moleong, 2017).

Thus, four criteria of data validity, each of them have an examining technique. The examining techniques, according to (Moleong, 2017) can be seen in table 2.

Table 2. Data Validity Examining Techniques

\begin{tabular}{ll}
\hline Criteria & Examining Techniques \\
& \\
\hline Credibility & Participation extension \\
& Observation persistence \\
Triangulation & Peer-review \\
& Referential adequacy \\
& Negative case study \\
& Member checking \\
& \\
& Detailed Description \\
Certainty & Dependency audit \\
Dependence & Trust Audit \\
Certainty & \\
\hline
\end{tabular}

In this study, the researcher uses the persistence technique of observation and peer-review. (Moleong, 2017) Observational persistence means looking for consistent interpretations in various related to a constant or tentative analysis process. So the continuation of observations in this study aims to increase accuracy and detail in analyzing the feasibility of the mathematics textbook material for grade VII 1st semester of 2017 revised edition based on Bell's criteria. Furthermore, peer-review is through discussion to strengthen the findings. (Moleong, 2017) suggests that peer-review techniques are carried out by exposing temporary results or the final results obtained by peers-discussion.

Moleong (2017) describes that the certainty criterion requires researchers to report the results of their research so that the description is carried out as carefully and accurately as possible, describing the context of the study. So the researchers provide reports carefully to explain the results of the suitability mathematics textbook's analysis While dependence is done by auditing. It completes the overall implementation records from the study results or analysis of the material in the seventh-grade mathematics 


\section{Hipotenusa Journal, 3 (1), June 2021}

Mahendra Wisnu Wardana, Leetahannee Kadah

textbook in the first semester of the 2017 revision. In (Moleong, 2017) auditing is a business concept, especially in the fiscal field which is used to check dependability and certainty. This is both happened toward the process or on the results or the output.

Based on the above background, the problem formulation in this study is how the feasibility of the mathematics textbook material for grade VII 1st semester of 2017 revised edition based on Bell's criteria? The aim of this research is to describe the feasibility of this textbook.

The results of this study are expected to be valid and improve the quality of textbooks to support the development of education in Indonesia to make it even better. Teachers' practical benefits can provide insight, overview, and be more selective in using textbooks as learning resources for students. The teacher must be more careful in the book's contents, especially the material in the book, provide suggestion, and correct it if there are errors in the textbook before it is delivered to the students. In contrast, for students, it can be used as a source of information about how to choose a good textbook and be more selective in selecting textbooks as a learning resource.

To provide direction and goals to be achieved in this research, it is necessary to emphasize the terms. According to (Mujiati, 2014) analysis can be defined as the decomposition of a complete information system into its parts to identify and evaluate problems, opportunities, obstacles that occur, and the expected needs so that improvements can be proposed. Meanwhile, feasibility, according to the Indonesian Dictionary/ Kamus Besar Bahasa Indonesia (KBBI), means something appropriate and valuable to find out a result. So the feasibility analysis is describing information to find out the products that are precious to do. In this study, the feasibility analysis is used to describe the material for mathematics textbook material for grade VII 1st semester of 2017 revised edition to determine its feasibility before being used for the teaching and learning process.

According to the Indonesian Dictionary $(\mathrm{KBBI})$, criteria are the measurements are the basis for an assessment or determination of one thing. (Lutviana, 2017) suggests that Frederick H. Bell is a well-known scientist, one of his works is Teaching and Learning Mathematics (In Secondary School). According to Bell, there are four book suitability criteria in the textbook, and there are criteria related to mathematical material, criteria related to the method of delivering the material, criteria related to physical 
characteristics, and criteria related to instructions for teachers used to analyze mathematics books. So Bell's criterion is the basis of assessment according to Bell scientists with four criteria for diagnosing mathematics books. In this study, only one of Bell's four criteria was used, namely criteria related to mathematics material to analyze this textbook. To avoid missed definition or understanding in this study, it is necessary to have operational definitions for the following terms. (1) The book referred to in this study is the students' mathematics textbook Grade VII 1st Semester with the Ministry of Education and Culture copyright in 2017. The field of study contains numbers, sets, algebra, and one-variable linear equations and inequalities. (2) There are four criteria for Bell, but this study only takes 1 criterion, namely criteria related to mathematics material. The first criterion contains 21 questions, but these questions are modified based on the curriculum on the analyzed students' book so that there are 20 questions for each chapter.

The analysis explains a complete information system into its parts which aimed to identify and evaluate problems, opportunities, obstacles that occur, and expected needs so that improvements can be proposed (Mujiati, 2014). Based on the description above, it can be concluded that analysis is the activity of describing or sorting out information based on specific criteria to evaluate the problem so that it can be corrected immediately.

Learning resources come from two words, namely source and learning. The source is commonly known by the terms origin, the beginning, and material. Learning is all events or activities that affect students' learning process (Zaman, Application of Active Learning in PAI Learning, 2020). Meanwhile, learning is a process of seeking experience. So learning resources are all materials that facilitate one process of gaining experience (Satrianawati, 2018). Then, (Susilana, 2007) states that learning resources are anything that supports the learning process, including service systems, learning materials, and the environment.

Textbooks contain material descriptions of specific subjects or fields of study, which are arranged systematically and have been selected based on specific objectives, learning orientation, and student development, to be assimilated (Rahmawati G., 2015). Mudzakir also conveys a similar definition. Textbooks are school books, teaching books, handbooks, or textbooks used in schools or educational institutions and are 


\section{Hipotenusa Journal, 3 (1), June 2021}

Mahendra Wisnu Wardana, Leetahannee Kadah

equipped with materials for training or student's handbooks (Mudzakir, 2003). Meanwhile, based on the understanding of textbooks according to the experts, it can be concluded that textbooks are lesson-books that have been tested for the feasibility of content from various aspects so that they can be used as a handbook for teachers and students in schools to support and facilitate teaching and learning activities in school.

Quality textbooks are books that can be used in the teaching and learning process. Textbooks function as teaching materials that are adapted to the current curriculum and following the level of education that students are taking. (Rahmawati G., 2015) explains some standards for determining the quality of textbooks, namely: (a) Point of view, (b) Clarity of concepts, (c) Relevant to curriculum, (d) Attracting interest, (e) Giving motivation, (f) Stimulating students' activity, (g) Illustrative, (h) Communicative, (i) Supporting subjects, (j) Appreciating individual differences, (k) Strengthening values. Based on the textbook quality standards above, it can be said that textbooks have an important role as a companion to teachers and students in teaching and learning activities, because textbooks can help students to grow their motivation and interest in learning for independent study based on the material listed in the textbook. According to (Hidayat, 2007) the existence of textbooks for teachers in schools is a very determining factor in the success or failure of an educational process in schools.

In choosing textbooks, the teachers must pay attention to the quality of the book from various aspects such as book cover, type of paper used, and book material based on the level of education. Meanwhile, Mathematics comes from Greek from the root word mathema which means knowledge or science or other similar words mathenin which means learning or thinking. (Siagian, 2016) argues that mathematics means knowledge gained by thinking (reasoning). Mathematics has characteristics there are: having abstract objects based on agreement, deductive thinking, having symbols that are empty meaning, paying attention to the overall discussion, being consistent in the system. Then, Mathematical objects are mental which cannot be sensed, seen, touched, or felt. From the explanation above, it can be concluded that mathematics is an abstract and consistent science or an exact science that is obtained by thinking and reasoning.

So a mathematics textbook is a student and teacher handbook that contains mathematics learning material to support the delivery of mathematical knowledge. 
Mathematics textbooks are expected to help teachers deliver material and give students motivation to learn mathematics at school and outside of school independently.

Experts defined the meaning of the curriculum as very diverse because of different bases and thought. Even though they are different, they still have similarities, namely the curriculum as a tool to achieve educational goals. The curriculum has a system that consists of various interrelated components and has only one educational goal. According to (Winarso, 2015) a curriculum is a set of plans and knowledge about the objectives, content, and learning materials and methods used as guidelines for implementing learning activities to achieve certain educational goals. In the National Standard Agency SIN 19-7057-2004 concerning the industrial-occupational hygiene and Work Safety Training Curriculum for the Company Doctors, the curriculum is a series of subjects and learning experiences with a specific purpose taught in a certain way and then evaluated.

From the description of the definition of curriculum above, it is concluded that the curriculum is a guideline and instrument that contains a series of plans regarding the objectives, content, and learning materials to achieve certain educational goals which are then carried out an evaluation so that educational goals can be achieved. So, the 2013 curriculum is a curriculum designed so that students can think critically to solve and fix problems. Currently, the Ministry of Education and Culture (Kemendikbud) has implemented the 2013 Curriculum, which is a development of the 2004 CompetencyBased Curriculum and the 2006 Education Unit Level Curriculum (KTSP).

According to Bell (Lutviana, 2017) four main criteria can be used to analyze mathematics textbooks based on Bell's criteria, which are as follows. (a) Criteria are related to mathematical material. Stating that the mathematics material contained in mathematics books is correct and precise and must be based on the achieved objectives and adapted to the conditions of the students participating in the teaching and learning activities. (b) Criteria relating to the method of delivering material. The method of delivering material is one of the essential things in evaluating mathematics books because it ensures the appropriateness of the teaching and learning methods used and to determine the suitability of the book with the level of intellectual development and students' abilities. (c) criteria related to physical characteristics. The physical character of the book also needs to be considered and evaluated. Still, the quality of the paper and 
print and the physical appearance of the book do not have to be used as the main requirements in choosing a book as a learning resource. (d) criteria relating to the instructions for teachers.

In general, in textbooks there are teacher instructions that are used to assist teachers in delivering material to be accepted by students quickly and in a structured manner. Many secondary schools' textbooks come with teacher editions or teacher guides that contain specific information and sections such as test guides, learning objectives, appendices, and introductory chapters, which are helpful for teachers in planning and teaching.

The 2013 curriculum on Mathematics is different from the previous curriculum. The previous curriculum directs the learning process to the abstract material, but in the 2013 curriculum starts from observing concrete problems, then to semi-concrete, and finally problem abstraction. In addition, if in the previous curriculum, students were only asked to memorize formulas to solve problems, but in the 2013 curriculum, the formulas are derived by students themselves. The problems on the number of questions have to be assigned by students only with basic formulas and understanding so that students could use not only formulas but also understand their origins.

The approach used in the 2013 curriculum is scientific. The scientific approach is considered as an approach that can develop the activeness and creativity of students because in this approach, there are important components, including observing, questioning, reasoning, trying, and presenting components so that they can support the learning process and its results. Learning outcomes are the final results that have been achieved by a person after carrying out a learning process that the results in these changes as follows: a). Behavior, b). Value System, c). Rich concepts, d). Abundance information (Zaman, Improving Learning Outcomes of Fiqh Subjects through the Application of the CTL Method and Giving Learning Motivation to Grade VII A Students of MTs Negeri Teras, 2013). Therefore, the student ish 2013 curriculum's approach, so it could be analyzed the approach's appropiateness model in the book toward the 2013 curriculum.

Based on the description above, the researcher expects this study to run optimally and in line with the research objectives regarding its feasibility. Then, based on Bell's four criteria, this research will use the first criteria related to mathematical material. 
Because the material is crucial in the book, if there is a material error, it will have fatal consequences for teachers and students who use it.

The topics discussed in the textbook must be based on the Permendikbud and adapted to the level or grade. The topics that must be presented in the mathematics textbook for grade VII 1st semester according to Permendikbud No.37 of 2018, namely, explaining and determining the order of integers (positive and negative) and fractions (ordinary, mixed, decimal, percent), explaining and calculating of powers of positive and negative integers number, explaining sets, subset, universal sets, empty sets, set complement, and performing binary operations on sets using contextual problems, explaining the algebraic form and calculating on the algebraic form (addition, subtraction, multiplication, and division), and describing linear equations and inequalities of one variable and its solutions.

\section{RESULTS AND DISCUSSION}

The suitability of Mathematical Material in CHAPTER I Numbers. Regarding the facts used in this entire chapter, it has been presented correctly so that this question is said to be according to Bell's criteria. The number chapter concept explains three numbers that are used as the initial concept in this chapter. So the mathematical concept is said to be following Bell's criteria. Mathematical skills in the numbers chapter are shown by finding the quantity of two numbers to match the skills. Regarding the mathematical principles. One of the principles of mathematics in the chapter on numbers can be seen by finding the number factor. The symbols and notations used in this chapter include addition, subtraction, multiplication, division, equal, not equal, number line. In this book, in the chapter on numbers, there are several printing errors that are found. So question 6 does not fit Bell's criteria. Question 7 The symbols used in the numbers chapter have matched, so question 7 meets Bell's criteria. Before entering into deeper material, the concept or introduction to the material is first presented to make it easier for students to understand the material. In this book there are also historical figures and mathematicians. So that it meets Bell's criteria for question 9. Moreover, in question 10, does the level of difficulty and accuracy meet the student's ability level? In this case, an alternative solution is found for the example question using the Last Common Multiple (KPK), where the previous KPK material has not been explained. Does the book use a modern approach or a traditional approach in presenting 


\section{Hipotenusa Journal, 3 (1), June 2021}

Mahendra Wisnu Wardana, Leetahannee Kadah

mathematics material? This book uses an approach in accordance with the applicable 2013 curriculum, namely the scientific approach of all aspects of the 5M (mengamati, menanya, mencoba, menganalisis, mengomunikasikan) observing, asking, trying, analyzing, communicating). The use of the approach in the number chapter meets Bell's $11^{\text {th }}$ criteria. Question 12, Does the book emphasize mathematical facts and skills, or does it emphasize mathematical concepts and principles? The entire chapter on numbers regarding the emphasis of facts and skills or concepts and principles has been fulfilled. So that Bell's $12^{\text {th }}$ criterion is appropriate. Question 13, Is the correct form of logic used in the proof of postulates/theorems? The logical form has been presented correctly in the chapter on numbers. It is seen how to solve examples of multiplication problems. Even though, in the chapter on numbers, it is found that there are solutions to problems that are not considered. So that it does not meet Bell's criteria to 14. Next, question 15, Are the evidence, explanation, and examples complete so that students who will use the book can understand it? In this book question 15 fits Bell's criteria. This question 16 does not meet Bell's criteria, because in the numbers chapter, there are common logical errors and confusing reasons. Students are asked to find the actual distance, but the space on the map is not presented in the question.

Moreover, question 17, Are math terms correctly defined and easy to understand? In the chapter on numbers, mathematical terms have been defined correctly so that they meet Bell's 17th criteria. Question 18, Is the use of mathematical terms correct? The use of mathematical terms has been used correctly. Is there a distinct difference between the undefined element, the defined element, and the theorem? In the chapter, the defined elements have been distinguished from the undefined elements. Examples of defined elements are to provide clear distinctions such as boxed, bold, and italicized. So that question 19 fits Bell's criteria. Question 20, Are all the topics that want to be taught included in the book? All Basic Competencies/Kompetensi Dasar (KD) in the numerical chapter are in accordance with KD in the 2013 curriculum of PERMENDIKBUD, and the topics to be taught have been presented in the book. Based on the similarity of content between KD in the book and in Permendikbud No.37 of 2018 so that the $20^{\text {th }}$ question meets Bell's criteria.

Suitability of Mathematical Material in CHAPTER II Sets. Question 1, Are math facts correct? In the chapter, the set of facts is shown in the use of member and non- 
member symbols. So that the mathematical facts match Bell's criteria. Question 2, is the mathematical concept correct? The idea of the set, in this case, is following Bell's criteria, seen from showing how to write the set-forming notation. Skill sets can be seen in how to solve problems.

So that question 3 about the correctness of math skills matches Bell's criteria. Examples of mathematical skills in solving problems related to everyday life and solving the problems are presented. Question 4, Are the principles of mathematics correct? The principle of mathematics is shown by presenting the set with 3 set representations. The symbols used in set chapters are standard and there are other notations used. So that question 5 meets Bell's criteria. In the chapter of sets, there are several printing errors that affect the understanding of the content of the material. Question 7, Does the material presented use too many symbols that are not appropriate so that it affects students' experience? The use of symbols in the set chapter is shown quite a lot, but symbols are relevant and do not affect student understanding. So question 7 meets Bell's criterion. Question 8, Is the basic structure of the mathematical system presented? In the set chapter based on question 8 , the basic structure has been presented correctly. Before entering into the set material, first, the concept of the set is presented early as an introduction to student understanding. So that question 8 meets Bell's criteria. In the set chapter, there is also a mathematician who discovered the set theory. So that it meets Bell's criteria for question 9. Question 10, Is the level of difficulty and accuracy in accordance with the level of student ability? Question 10 has met Bell's criteria.

The student's level of difficulty and ability is following the level of the student being taken. Question 11, Does the book use a modern approach or a traditional approach in presenting mathematics material? The set material in this book uses a scientific approach of all aspects of the 5M (observing, asking, trying, analyzing, communicating). So that it meets Bell's criteria. Therefore, the set chapter has emphasized mathematical facts and skills and emphasized mathematical concepts and principles. So that in the chapter, the set is following Bell's criteria for question 12. In question 13, is the correct form of logic used in the proof of theorem? The logical form has been presented correctly so that it is said to be appropriate. In question 14, Is problem-solving considered in the book? So question 14 has already been displayed to 
meet Bell's criteria. Question 15, Are the evidence, explanation, and examples complete so that students who will use the book can understand it? Evidence, descriptions, and examples have been fully presented in the set chapter, and making it easier for students to use the book. So that question 15 is said to have met Bell's criteria. Question 16, Does the text show common logical errors such as confusing reasons, accepting truths that contradict theorems, and using unproven theorems to prove theorems? The logic in the set chapter has been described correctly. The mathematical terms in set chapters are correctly defined. Example of an empty set explanation. So that it can be said to have met Bell's criteria for question 17.

Question 18, Is the use of mathematical terms correct? One of the mathematical term's applications on empty sets has been used correctly, thus satisfying Bell's criteria. Question 19, Is there a clear distinction between the undefined element, the defined element and the theorem? Differences have been clearly presented, namely by providing boxes to explain certain definitions. Question 20, Are all the topics you want to teach included in the book? All topics to be taught are already in the book and KD in the set chapter is in line with KD in the 2013 curriculum PERMENDIKBUD. Based on the similarity of content between KD in the book and in Permendikbud No.37 of 2018 so that the 20th question meets Bell's criteria.

The Suitability of Mathematical Material in CHAPTER III Algebra. Facts in the Algebra chapter are shown in the introduction of syllable names, coefficients, variables, and constants so that the mathematical facts are proven according to Bell's criteria. Question 1. Question 2, Is the mathematical concept correct? The concept of algebra is shown by providing examples and explanations of the names of algebraic forms based on the number of terms. Question 3, Are math skills correct? Mathematical skills are shown by solving some example's questions in the alternative solutions.

Meanwhile, question 4, Are the principles of mathematics correct? Mathematical principles have been presented correctly. It could be seen of how to think independently to solve the problems. Question 5, Are standard math symbols and other notations used? In the algebra chapter, symbols and notations are used, one of which is the use of symbols or variables $\mathrm{x}$ and $\mathrm{y}$. In question 6 , does the book contain a number of typographical errors and wrong answers that affect understanding the material? The 
algebra chapter contains several typographical errors and solutions that can influence students in understanding algebraic material.

Question 7, Does the material presented use too many symbols that are not appropriate so that it affects students' understanding? The use of symbols is appropriate and does not affect students' understanding, so it can be said that it fulfills Bell's criteria. Question 8, Is the basic structure of the mathematical system clearly presented? The basic structure of the mathematical system is clearly presented. One of them is to find the width of a flat area. First, the formula for finding the area of a flat area is presented. In algebra, there are also mathematical figures. So that it meets Bell's criteria for question 9. Question 10, Is the level of difficulty and accuracy in accordance with the level of student ability? Question 10 does not meet Bell's criteria, there are findings in the book that the level of difficulty does not match the students' abilities.

Question 11, Does the book use a modern approach or a traditional approach in presenting mathematics material? The algebra material in this book has used a modern approach in presenting mathematics material, namely the scientific approach of all aspects of the $5 \mathrm{M}$ (observing, asking, trying, analyzing, communicating). The algebra chapter that deals with question 12 fulfill Bell's criteria. Question 13, Is the correct form of logic used in the proof of postulates/theorems? It could be seen in the book how to multiply the algebraic form $(x+a) \times(x+b)$. Problem-solving in the algebra chapter has the findings of examples of questions that do not consider the problem-solving process so that it affects student understanding so that it does not meet the 14th criterion. Question 15, Is the evidence, explanation, and examples complete so that students who will use the book can understand it? Evidence, explanations, and examples have been presented in full in the algebra chapter making it easier for students to use the book. So question 15 is said to have met Bell's criteria. This question 16 does not fit Bell's criteria, because in the numbers chapter, there are common logical errors and confusing reasons. The problem presented is that there is no explanation regarding the weight (kilogram) of rice using only units of rice sacks. However, in the 'Ayo Mengamati' activity (Let's Observe activity), a weight of rice is found, which is not previously explained in the problem.

Question 17, Are math terms correctly defined and easy to understand? In the algebra chapter, mathematical terms have been defined correctly so that they meet Bell 
17's criteria. Question 18, Is the use of mathematical terms correct? Mathematical terms have been presented accurately, one of which is about determining like terms. Question 19 , Is there a clear distinction between the undefined element, the defined element and the theorem? In the algebra chapter, there is a finding that the defined and not defined elements are not differentiated.

Question 20, Are all the topics which want to teach included in the book? All topics to be taught are already in the book, while the KD in the algebra chapter is in accordance with the KD in the 2013 Curriculum Permendikbud. Based on the similarity of content between KD in the book and in Permendikbud No.37 of 2018 so that the 20th question meets Bell's criteria.

Conformity of Mathematical Material in CHAPTER IV One-Variable Linear Equations and Inequalities. Question 1, Are math facts correct? In the chapter on linear equations and inequalities, one factual variable is shown in the presentation of the problem using equations. So that the mathematical facts match Bell's criteria. Question 2 , is the mathematical concept correct? The concept of linear equations and inequalities of one variable in this case is in accordance with Bell's criteria, seen from grouping the truth of several sentences that have been previously presented.

Question 3, Are math skills correct? Mathematical skills are shown by solving example problems and solving them. Question 4, Are the principles of mathematics correct? Mathematical principles are shown by grouping into one-variable linear equations, one-variable linear inequalities, two-variable linear equations, and onevariable quadratic equations. Question 5, Are standard math symbols and other notations used? In chapter IV, there are unstandardized symbols so that they do not meet the bell criteria. In question 6, does the book contain a number of typographical errors and wrong answers that affect understanding the material? The one-variable linear equations and inequalities chapter found a typo. The error is in the word "Ayo Bernalar" "Let's We Reason" because there is no Let's We Reason feature in the student book.

Question 7, Does the material presented use too many symbols that are not appropriate to affect students' understanding? The use of symbols is appropriate and does not affect students' understanding, so it can be said that it fulfills Bell's criteria. Question 8, Is the basic structure of the mathematical system clearly presented? The 
basic structure of the mathematical system is clearly presented. One of them can be seen on how to solve the linear equations and inequalities of one variable which previously presented the one variable equation to show the difference. In the chapter on linear equations and inequalities of one variable, there are also figures of mathematicians. So that it meets Bell's criteria for question 9. Question 10, Is the level of difficulty and accuracy in accordance with the level of student ability? Question 10 has met Bell's criteria, the level of difficulty and ability of the student is appropriate. Question 11, Does the book use a modern approach or a traditional approach in presenting mathematics material? The material of linear one-variable equations and inequalities in this book uses an approach in accordance with the applicable 2013 curriculum, namely the scientific approach of all aspects of the 5M (observing, asking, trying, analyzing, communicating). In the chapter on linear equations and inequalities, one variable emphasizes mathematical facts and skills and emphasizes mathematical concepts and principles. So that in the linear equations and inequalities chapter one variable has met Bell's criteria for question 12. In question 13, is the correct logic form used in the proof of theorem? Underlining from the findings in the book, it can be said that question 13 is in accordance with Bell's criteria. In question 14 Is problem solving considered in the book? Already meet Bell's criteria. Question 15, Are the evidence, explanation and examples complete so that students who will use the book can understand it?. Evidence, explanations and examples have been fully presented in the chapter on linear equations and inequalities of one variable, making it easier for students to use the book. So question 15 has met Bell's criteria. Whereas the question 16 does not fit Bell's criteria, because in the numbers chapter there are common logical errors and confusing reasons. It is said that "After you do activities (1) - (4), ..." but in the previous book there are no activities (1) - (4) as mentioned. The mathematical terms in set chapters are correctly defined. An example of how to simplify the fraction form equation using the KPK. So that it can be said to have met Bell's criteria for question 17. Question 18, Is the use of mathematical terms correct? Mathematical terms have been presented correctly, including simplifying the fractional equation by multiplying the KPK number. Question 19 , Is there a clear distinction between the undefined element, the defined element and the theorem? Differences have been clearly presented, namely by providing boxes to explain certain definitions. Question 20, Are all the topics you want to teach included in 
the book? All the topics to be taught are already in the book. Significantly the previous chapters, KD in the equations and inequality chapter of one variable linear is in accordance with KD in the 2013 curriculum PERMENDIKBUD. Based on the similarity of content between KD in books and in Permendikbud No.37 of 2018 so that the $20^{\text {th }}$ question meets Bell's criteria.

After analyzing the book, it is followed by Peer-Review by Junior High School teachers. After peer-review, there are differences of opinion and have been discussed between researchers and peers. Differences of opinion are found in the numbers chapter, and the set chapters, each of them has one criterion. In the algebra chapter, there are two criteria that are inconsistent with peer experience. In the chapter on linear equations and inequalities of one variable, there is no difference of opinion or thought. The difference in the number chapter is in the criteria for question 10. Based on the results of the discussion, the difference lies in the delivery of KPK material. The KPK material has not been delivered in the book, but students have studied the KPK material at the previous education level, so it does not affect students ' learning. The different opinion in the set chapter is in the $13^{\text {th }}$ question. Based on the results of the discussion, the proof of the theorem is not overly emphasized because the students' abilities seem hard to face the logic of proof. Furthermore, the differences in the algebra chapter contained in questions 14 and 16. Based on the results of the discussion, when looking back 2013 curriculum objectives, students are required to think critically, so solving the problem in question 14 does not affect students' understanding. The last difference is the general logic error, which is explained in the problem-solving problem book using the unit size of rice sacks. But then it is discovered that the unit of mass $/ \mathrm{kg}$ (weight) of rice is not previously explained. Based on the results of the discussion, rice generally has a mass (on $\mathrm{kg}$ ), so even though it is not previously explained, it would not affect students' understanding of the problems presented in the book.

Based on the observational data contained in Appendix 5, the analysis and discussion of the suitability of the observations related to the material based on Bell's criteria have been carried out, a recapitulation of the results of the analysis is presented in table 3. 
Jurnal Hipotenusa, 3 (1), June 2021

Mahendra Wisnu Wardana, Leetahannee Kadah

Table 3. Recapitulation of Mathematical Material Suitability Analysis Results

\begin{tabular}{lllll}
\hline No & Chapter & $\begin{array}{l}\text { Number of } \\
\text { questions }\end{array}$ & $\begin{array}{l}\text { Number of } \\
\text { suitable questions }\end{array}$ & Percentage \\
\hline 1 & Numbers & 20 & 16 & $80 \%$ \\
2 & Sets & 20 & 19 & $95 \%$ \\
3 & Algebra & 20 & 15 & $75 \%$ \\
4 & linear equations & 20 & 17 & $85 \%$ \\
& $\begin{array}{l}\text { and inequalities of } \\
\text { one variable }\end{array}$ & & & \\
\hline
\end{tabular}

Based on table 3, it can be seen that the chapter number, appropiate questions on Bell's criteria, there are 16 questions out of 20 questions with a percentage of $80 \%$ which means good or appropriate when seen in table 3 Category Percentage of Material Suitability, the sets chapter there are 19 appropriate questions from 20 questions so that The percentage is $95 \%$ indicating the category is very good, for the algebra chapter the appropriate questions are 15 questions out of 20 questions with a percentage of $75 \%$, it menasthat it is good or appropriate category. The last chapter of the linear equations and inequalities of one variable contained 17 questions that match Bell's criteria out of 20 questions with a percentage of $85 \%$ included to be a very good category. Then the percentage of each chapter is gained from the average of percentage's suitability of the material as follows:

Table 4. Feasibility of Mathematics Material's Persentage

\begin{tabular}{lll}
\hline No & Chapter & Percentage \\
\hline 1 & Numbers & $80 \%$ \\
2 & Sets & $95 \%$ \\
3 & Algebra & $75 \%$ \\
4 & linear equations and inequalities of one variable & $85 \%$ \\
& Feasibility Percentage's Average & $83,75 \%$ \\
\hline
\end{tabular}

Based on the results of the calculations in table 4, the analyis of Mathematics material on 2013 curriculum toward Bell's criteria is $83.75 \%$ or very good category. Furthermore, there is a difference opinion between the results of the researcher's analysis and peer-review. The first difference is in the number chapter, the previous fraction material has not been conveyed about KPK material. But KPK material has been taught at the previous level, namely in elementary school. To solve a problem such as the question 10's case, students will usually immediately equate the denominator without paying attention to the use of KPK.

The second difference opinion in the $13^{\text {th }}$ question set chapter, from the teacher's experience of the theorem of proof of a material is not emphasized in details, only 
briefly conveyed. Because the ability of grade VII students is still difficult in proving the theorem. Looking at the current 2013 curriculum, for the future, the proof of the theorem will be conveyed in more detail because theorem's proof can affect the students' mindset to be more creative. So that the goals of the 2013 curriculum can be achieved.

The third difference of opinion is found in the algebra chapter, for problem solving if it is related to the 2013 curriculum, students are required to think critically. So when looking back at the case of question 14 in the algebra chapter, it does not matter if it is not explained. The goal is that students can solve these problems independently.

However, the fourth difference is still in the algebra chapter, logical errors in the algebra chapter of question 16. The problem that occurs is the use of mass units of rice. Previously the unit used is the unit of rice sacks, but in the following context it changed to kilograms of rice (mass on $\mathrm{kg}$ ). In general, the mass unit of rice is kilograms. So students can still solve the presented problems/questions and do not affect student understanding.

\section{CONCLUSION}

Based on the results of the discussion and analysis, it could be concluded that the suitability between the material in the Mathematics Student Book for Grade VII $1^{\text {st }}$ Semester and the material based on Bell's criteria for the numbers and algebra chapters based on table 3 for this chapter is in a good or appropriate category. In the set and linear equations and inequalities chapter, one variable based on table 3 belongs to be the excellent category. The average suitability of the mathematics material from each chapter in the textbook against Bell's criteria is $83.75 \%$ and is supported by the results of the validity of the data through forms and discussions with peers. Finally, the appropriateness of the mathematics textbook material grade VII $1^{\text {st }}$ semester 2017 revised edition based on Bell's criteria are categorized as very good.

\section{REFERENCES}

Hanafy, M. S. (2014). Konsep Belajar dan Pembelajaran. Lentera Pendidikan, Vol.17(1):66-67.

Hardani, d. (2020). Metode Penelitian Kualitatif \& Kuantitatif. Yogyakarta: Pustaka Ilmu. 
Jurnal Hipotenusa, 3 (1), June 2021

Mahendra Wisnu Wardana, Leetahannee Kadah

Hidayat, D. R. (2007). Ilmu dan Aplikasi Pendidikan (Bagian 3 Pendidikan Disiplin Ilmu). Bandung: PT. Imperial Bhakti Utama.

Lutviana, I. (2017). Analisis Kelayakan Materi Buku Matematika Kurikulum 2013 Edisi Revisi 2016 Kelas VII Bab Segiempat dan Segitiga Berdasarkan Kriteria Bell. Skripsi tidak diterbitkan, 12.

Melissa, M. (2015). Analisis Buku Siswa Matematika Kelas VIII Semester 1 Berdasarkan Kriteria Bell. Skripsi Tidak Diterbitkan, 1-2.

Moleong, L. J. (2017). Metodologi Penelitian Kualitatif. Bandung: PT. Remaja Rosdakarya.

Mudzakir. (2003). Penulisan Buku Teks Bahasa Arab. Seminar Nasional Pengajaran Bahasa Arab (p. 3). Bandung: Program Pendidikan Bahasa Arab JPBA FPBS UPI.

Mujiati, H. ( 2014). Analisis dan Perancangan Sistem Informasi Stok Obat pada Apotek Arjowinangun. Speed Journal, Vol.11(2):24-25.

Muljono, P. (2007, Januari 1). Kapal Itu Bernama UN. Buletin BNSP, p. 20.

Rahmawati, G. (2015). Buku Teks Pelajaran Sebagai Sumber Belajar Siswa di Perpustakaan Sekolah di SMAN 3 Bandung. EduLib, 5(1):106-107.

Rahmawati, G. (2015). Buku Teks Pelajaran Sebagai Sumber Belajar Siswa di Perpustakaan Sekolah di SMAN 3 Bandung. EduLib, 5(1):106-107.

Rasimin, R. ( 2019). Metodologi Penelitian: Pendekatan Praktis Kualitatif. Yogyakarta: Trussmedia Grafika.

Satrianawati. (2018). Media dan Sumber Belajar. Yogyakarta: Deepublish.

Siagian, M. D. (2016). Kemampuan Koneksi Matematik dalam Pembelajaran Matematika. MES (Journal of Mathematics Education and Science), Vol.2(1):59-60.

Sugiyono. (2018). Metode Penelitian Kombinasi (Mixed Methods). Bandung: Alfabeta, $\mathrm{cV}$.

Susilana, R. (2007). Ilmu dan Aplikasi Pendidikan (Bagian 2 Pendidikan Disiplin Ilmu). Bandung: PT. Imperial Bhakti Utama.

Winarso, W. (2015). Dasar Pengembangan Kurikulum Sekolah. Cirebon: CV. Confident. 
Hipotenusa Journal, 3 (1), June 2021

Mahendra Wisnu Wardana, Leetahannee Kadah

Zaman, B. ( 2013). Peningkatan Hasil Belajar Mata Pelajaran Fiqih melalui Penerapan Metode CTL dan Pemberian Motivasi Belajar pada Siswa Kelas VII A MTs Negeri Teras. Boyolali : Tesis: Pascasarjana UMS.

Zaman, B. (2020). Penerapan Active Learning dalam Pembelajaran PAI. Jurnal AsSalam , 4 (1), 13-27. 